\title{
Analisis Pola Konsumsi Masyarakat Kota Batam Berdasarkan Penggunaan $E$-Money Berbasis Aplikasi
}

\author{
Wan Maharani S.S ${ }^{1)}$ Arif Darmawan ${ }^{2 *}$ \\ Politeknik Negeri Batam \\ Program Studi Akuntansi Manajerial \\ Jl. Ahmad Yani, Batam Centre, Batam 29461, Indonesia \\ ${ }^{1)}$ e-mail: wan.maharani23@gmail.com \\ ${ }^{2)}$ e-mail: darmawan.polibatam@ac.id
}

\begin{abstract}
Abstrak
Penelitian ini bertujuan untuk menganalisis penggunaan e-money berbasis aplikasi pada masyarakat Kota Batam khususnya generasi Z (rentang usia 19-24 tahun) dan bagaimana pola konsumsi masyarakat dengan penggunaan $e$ money tersebut. Populasi pada penelitian ini adalah masyarakat Kota Batam dengan teknik judgement sampling, sehingga sampel didapat sebanyak 318 responden. Teknik analisis data yang digunakan adalah analisis deskriptifkuantitatif. Hasil penelitian menunjukkan bahwa aplikasi e-money yang paling banyak digunakan oleh masyarakat Kota Batam adalah Dana Dompet Digital. Selanjutnya diketahui bahwa pengeluran konsumsi baik makanan maupun non makanan dengan menggunakan e-money berbasis aplikasi di Kota Batam relatif masih rendah dan terdapat sedikit pergeseran pola konsumsi pada masyarakat, yaitu pengeluaran paling banyak terjadi pada kelompok konsumsi hiburan.
\end{abstract}

\section{Kata Kunci: E-money, Pola Konsumsi, Masyarakat}

\begin{abstract}
This study aims to analyze the use of application-based e-money in the people of Batam City specially for Z generation (age 19-24) and how people's consumption patterns with the use of e-money. The population in this study is the people of Batam City with judgment sampling techniques, so that the sample obtained as many as 318 respondents. The data analysis technique used is descriptive-quantitative analysis. The results showed that the e-money application that was most widely used by the people of Batam was Dana. Furthermore it is known that expenditure for consumption of both food and non-food using application-based e-money in Batam City is still relatively low and there is a slight shift in consumption patterns in the community, which is the most expenditure occurs in the entertainment consumption group.
\end{abstract}

Keywords: E-money, Consumption Pattern, Society.

\section{PENDAHULUAN}

Revolusi industri 4.0 saat ini menjadikan teknologi sebagai bagian penting dalam kehidupan manusia. Pemanfaatan teknologi ini membuat pekerjaan manusia menjadi lebih efektif dan efisien. Sebagai salah satu negara berkembang, Indonesia terus berproses menuju masyarakat yang berorientasi digital. Proses digitalisasi dilakukan pada hampir setiap aspek termasuk perekonomian, salah satunya mengenai sistem pembayaran. Sistem pembayaran di Indonesia yang semula dilakukan secara tunai menggunakan uang perlahan mulai tergeser dengan pembayaran secara elektronik atau yang biasa disebut e-money. E-money atau uang elektronik adalah alat pembayaran dalam bentuk elektronik dimana nilai uangnya disimpan dalam media elektronik tertentu. ${ }^{1}$

\footnotetext{
${ }^{1}$ Dapat diakses https://www.bi.go.id/id/edukasiperlindungan-konsumen/edukasi/produk-dan-jasa$\underline{\text { sp/uang-elektronik/Pages/default.aspx }}$
}

*) Corresponding author 
Terdapat dua jenis e-money yaitu berbasis aplikasi (server based) dan berbasis kartu (card based). Sistem pembayaran menggunakan e-money ini didukung oleh pemerintah Indonesia melalui program Gerakan Nasional Non Tunai (GNNT). Program yang dicanangkan pemerintah tersebut memiliki tujuan utama, yaitu meningkatkan kesadaran masyarakat terhadap penggunaan instrumen non tunai. ${ }^{2}$ Saat ini sudah banyak jenis e-money yang berkembang dimasyarakat, baik milik swasta maupun negara. Survei yang dilakukan iPrice Group dan App Annie pada kuartal kedua 2019 menunjukkan Gopay, OVO dan Dana meduduki peringkat tiga teratas e-money berbasis aplikasi terpopuler di Indonesia. ${ }^{3}$

Faktor keamanan dan kemudahaan menjadi alasan utama masyarakat memilih pembayaran menggunakan e-money. Selain itu, masyarakat saat ini juga lebih menyukai segala hal yang praktis, seperti $e$ money yang dapat digunakan setiap saat. Beberapa hal tersebut yang menyebabkan penggunaan e-money dimasyarakat semakin meningkat, khususnya di Indonesia. Peningkatan penggunaan e-money dimasyarakat ini diiringi dengan kenaikan tingkat konsumsi serta terjadinya perubahan pada pola konsumsi masyarakat. Hal ini didasari fakta bahwa masyarakat saat ini lebih banyak mengalokasikan uangnya pada konsumsi non pangan. ${ }^{4}$

Penelitian yang dilakukan di Brazil mengenai permintaan uang digital dan dampaknya terhadap perekonomian menunjukkan adanya hasil yang signifikan bagi perekonomian dengan peningkatan konsumsi dan perubahan pola konsumsi (Dias, Silva, \& Dias, 2000). Penelitian lain dilakukan Cobla \& Assibey (2018) menyimpulkan bahwa mahasiswa yang menggunakan uang digital menghabiskan 20 Cedi Ghana lebih banyak daripada yang tidak menggunakan uang digital.

Penelitian lain yang dilakukan oleh Igamo \& Falianty (2018) mengenai dampak $e$-money terhadap

\footnotetext{
${ }^{2}$ Dapat diakses https://www.bi.go.id/id/ruangmedia/siaran-pers/pages/sp 165814.aspx

${ }^{3}$ Dapat diakses

https://www.cnnindonesia.com/teknologi/2019081315 4902-185-420933/pengguna-aplikasi-dompet-digitaldi-indonesia-naik

${ }^{4}$ Dapat diakses

https://katadata.co.id/infografik/2019/04/11/transaksidigital-ubah-pola-konsumsi-masyarakat
}

efisiensi sistem pembayaran dan subtitusi menunjukkan bahwa $e$-money meningkatkan pengeluaran konsumsi pribadi masyarakat.

Penelitian Indonesia yang dilakukan oleh Ramadani (2016) menunjukkan adanya pengaruh yang positif antar kartu debit dan e-money terhadap pengeluaran mahasiswa. Penelitian mengenai pengaruh Alat Pembayaran Menggunakan Kartu (APMK) di Kota Palembang menunjukkan hasil yang signifikan terhadap pola konsumsi masyarakat (Basri \& Seto, 2018). Penelitian mengenai pengaruh sistem transaksi non tunai di Surabaya menunjukkan adanya pengaruh satu arah pada tingkat konsumsi masyarakat (Nelasari \& Cahyono, 2018). Khairi \& Gunawan, (2019) menliti mengenai pengaruh APMK dan $e$ money terhadap konsumsi masyarakat Aceh menunjukkan hasil yang positif.

Penelitian ini bertujuan untuk Penelitian ini bertujuan untuk menganalisis penggunaan e-money berbasis aplikasi pada masyarakat Kota Batam dan bagaimana pola konsumsi masyarakat dengan penggunaan e-money tersebut. Penelitian ini berbeda dari penelitian-penelitian terdahulu yang menggunakan e-money berbasis kartu. Penelitian ini menggunakan e-money berbasis aplikasi yang belum banyak dilakukan sebelumnya. Penelitian ini juga belum pernah dilakukan khususnya terhadap masyarakat di Kota Batam.

Penelitian ini merumuskan beberapa pertanyaan penelitian, pertama, apa saja e-money berbasis aplikasi yang digunakan masyarakat Kota Batam. Kedua, apakah e-money berbasis aplikasi yang paling sering digunakan masyarakat Kota Batam. Ketiga, apa alasan masyarakat menggunakan $e$-money berbasis aplikasi. Ketiga, berapa sering masyarakat menggunakan $e$ money berbasis aplikasi dalam sebulan. Keempat, apakah kelompok konsumsi dengan transaksi yang paling banyak menggunakan e-money berbasis aplikasi. Kelima, bagaimana pola konsumsi bahan pokok dengan menggunakan e-money berbasis aplikasi.

Keenam, bagaimana pola konsumsi bahan makanan hewani dan bahan makanan nabati dengan menggunakan e-money berbasis aplikasi. Ketujuh, bagaimana pola konsumsi minuman dan makanan jadi dengan menggunakan e-money berbasis aplikasi. Kedelapan, bagaimana pola konsumsi fasilitas rumah tangga dengan menggunakan e-money berbasis aplikasi. Kesembilan, bagaimana pola konsumsi transportasi dengan menggunakan e-money berbasis aplikasi. Kesepuluh, bagaimana pola konsumsi fashion dengan menggunakan $e$-money berbasis aplikasi.

Kesebelas, bagaimana pola konsumsi komunikasi dengan menggunakan e-money berbasis aplikasi. Kedua belas, bagaimana pola konsumsi untuk 
hiburan dengan menggunakan e-money berbasis aplikasi. Ketiga belas, bagaimana pola konsumsi untuk pembayaran tagihan dengan menggunakan $e$-money berbasis aplikasi. keempat belas, bagaimana pola konsumsi masyarakat secara keseluruhan dengan menggunakan e-money berbasis aplikasi. Kelima belas, apakah terdapat perubahan pola konsumsi masyarakat dengan menggunakan e-money berbasis aplikasi

\section{Teori Konsumsi Ernst Engel}

\section{TINJAUAN LITELATUR}

Teori konsumsi menurut Engel (1821-1896) dalam Nicholson (1997) menyatakan bahwa saat pendapatan meingkat, proporsi pendapatan yang dihabiskan untuk membeli makanan berkurang, bhakan jika pengeluaran aktual untuk makanan meningkat. Hal ini berarti hukum engel menyatakan bahwa tingkat kesejahteraan dikatakan membaik bila perbandingan pengeluaran untuk konsumsi makanan cenderung semakin menurun dan sebaliknya pengeluaran untuk non makanan semaking meningkat. Adanya pergeseran permintaan konsumsi tersebut dikarenakan beberapa faktor seperti, (a) tingkat pendapatan perkapita (percapita income) masyarakat, (b) cita rasa atau selera (taste) konsumen terhadap barang itu, (c) harga barang lain (prices of related goods), terutama barang pelengkap (complementary goods) dan barang pengganti (substitution goods) dan (d) harapan atau perkiraan konsumen (consumer expectation) terhadap harga barang yang bersangkutan.

\section{Teori Konsumsi Keynes}

Keynes dalam mengembangkan teorinya mengandalkan analisis statistic dan juga membuat dugaan-dugaan tentang konsumsi, menyatakan bahwa jumlah konsumsi saat ini (current disposable income) berhubungan langsung dengan pendapatan. Hubungan antar kedua variable tersebut dapat dijelaskan melalui fungsi konsumsi. Fungsi konsumsi menggambarkan tingkat konsumsi pada berbagai tingkat pendapatan. Fungsi konsumsi Keynes menghasilkan dugaandugaan tentang teori konsumsi yaitu adalah sebagai berikut:

a. Kecenderungan mengkonsumsi marginal (marginal propencity to consume) yaitu kenaikan konsumsi sebagai akibat kenaikan pendapatan sebesar satu satuan berkisar antara 0 dan 1. Asumsi ini menjelaskan bahwa jika pendapatan seseorang semakin tinggi maka semakin tinggi pula konsumsi dan tabungannya. b. Rasio konsumsi terhadap pendapatan, yang disebut kecenderungan mengkonsumsi rata-rata (average propenscity to consume) turun ketika pendapatan naik karena sebagian sisa dari pendapatannya dialokasikan untuk tabungan. Menabunng adalah sesuatu yang mewah sehingga menurut Keynes, proporsi tabungan orang kaya lebih besar daripada orang miskin.

c. Pendapatan merupakan determinasi konsumsi yang peting dan tingkat bunga dianggap tidak memiliki peran penting.

Berdasarkan teori Keynes di atas, dapat ditarik kesimpulan bahwa konsumsi sangat dipengaruhi oleh besarnya pendapatan.

\section{Sistem Pembayaran}

Menurut UU No. 23 tahun 1999 tentang Bank Indonesia, sistem pembayaran adalah suatu sistem yang mencakup seperangkat aturan, lembaga, dan mekanisme, yang digunakan untuk melaksanakan pemindahan dana guna memenuhi suatu kewajiban yang timbul dari suatu kegiatan ekonomi. ${ }^{5}$ Sistem pembayaran di Indonesia terus mengalami perkembangan dari masa ke masa. Perkembangan sistem pembayaran di Indonesia berawal dengan menggunakan sistem barter, yaitu kegiatan menukar barang atau jasa antara dua pihak tanpa perantara uang. Seiring perkembangan zaman sistem ini mulai tergeser oleh hadirnya uang kartal (uang kertas dan logam) sebagai instrumen pembayaran tunai. Selanjutnya sistem pembayaran terus berkembang dengan muculnya sistem pembayaran non tunai paper based seperti cek dan bilyet giro. hingga di era digital saat ini, sistem pembayaran juga terus berkembang menyesuaikan dengan perkembangan teknologi dengan hadirnya berbagai uang elektronik atau $e$ money baik berbasis kartu maupun berbasis aplikasi

\section{Electronic Money}

Pengertian e-money menurut Bank of Internationel Seattlement adalah suatu produk stored value atau prepaid card dimana uang yang dimiliki disimpan dalam media elektronik milik seseorang. ${ }^{6}$ Nilai yang terdapat di dalam e-money didapat jika pemilik melakukan penyetoran sejumlah uang tunai kepada penerbit maupun agennya. Cara lain adalah dengan mendebet rekening di bank untuk disimpan

\footnotetext{
${ }^{5}$ Dapat diakses https://www.bi.go.id/id/tentangbi/uu-bi/Contents/Default.aspx

${ }^{6}$ Dapat diakses di

https://www.bis.org/publ/bisp01.htm
} 
dimedia elektronik miliknya. Terdapat dua jenis $e$ money, yaitu $e$-money berbasis aplikasi (server based) dan $e$-money berbasis kartu (card based).

\section{Pola Konsumsi}

Menurut Kamus Besar Bahasa Indonesia (KBBI), pola adalah bentuk (struktur) yang tetap, sedangkan konsumsi adalah pengeluaran yang dilakukan atas pemakaian barang hasil produksi untuk memenuhi kebutuhannya. Menurut Moehadi (1981) pola konsumsi diartikan sebagai tanggapan aktif yang diberikan manusia terhadap lingkungan baik alam maupun sosial yang berhubungan dengan kebudayaan suatu masyarakat, dimana tanggapan aktif tersebut dapat berbentuk pemenuhan primer dan sekunder.Pola konsumsi dapat didefinisikan sebagai suatu kondisi dimana masyarakat memiliki kecenderungan untuk melakukan dalam memenuhi kebutuhan primer maupun sekunder, pangan dan non pangan.

Penelitian terdahulu mengenai pola konsumsi masyarakat berdasarkan penggunaan $e$-money belum banyak dilakukan, tetapi terdapat beberapa penelitian yang cukup relevan. Pertama, Dias, Silva \& Dias (2000) meneliti tentang permintaan uang digital dan dampaknya terhadap ekonomi di Brazil. Hasil penelitian tersebut menunjukkan bahwa uang digital berpengaruh signifikan terhadap perekonomian. Salah satu dampaknya yaitu, pergeseran konsumsi masyarakat yang cukup besar dari makanan ke non makanan.

Penelitian selanjutnya mengenai perbedaan gender dalam minat menggunakan e-money berdasarkan theory of planned behavior. Penelitian tersebut menggunakan metode survei terhadap 300 orang pelanggan bank syariah di Kota Semarang, Indonesia. Terdapat tiga temuan dalam hasil penelitian tersebut. Pertama, sikap berpengaruh positif terhadap minat menggunakan e-money pada kedua gender. Kedua, untuk pria, norma subyektif memiliki efek positif terhadap minat menggunakan e-money, sedangkan wanita tidak signifikan. Ketiga, kontrol prilaku belum secara signifikan meningkatkan minat menggunakan e-money terutama pada pria (Farida, Ardyan, \& Nuryakin, 2016).

Cobla \& Assibey (2018) selanjutnya meneliti bagaimana penggunaan uang digital mempengaruhi perilaku pengeluaran mahasiswa di Ghana. Penelitian tersebut menggunakan 506 mahasisiwa dari University of Ghana sebagai sampel dan dianalisis menggunakan metode ordinary leased squared. Hasil dari penelitian menunjukkan bahwa mahasisiwa yang menggunakan uang digital secara aktif menghabiskan 20 Cedi Ghana perbulannya. Hal ini lebih banyak dari pengeluaran yang dilakukan mahasisiwa yang tidak menggunakan uang digital.
Igamo \& Falianty (2018) meneliti mengenai dampak e-money terhadap efisiensi sistem pembayaran dan subtitusi. Penelitian tersebut menggunakan data pembayaran non tunai khususnya e-money dari BPS dan Bank Indonesia periode 2007-2017. Hasilnya menunjukkan bahwa e-money meningkatkan pengeluaran konsumsi pribadi masyarakat.

Penelitian mengenai e-money di dalam negeri juga pernah dilakukan. Ramadani (2016) meneliti mengenai pengaruh kartu debit dan e-money terhadap pengeluaran konsumsi mahasiswa. Sampel penelitian tersebut adalah 150 mahasiswa Universitas Negeri Malang, dengan pengujian regresi linier berganda. Hasilnya menunjukkan adanya pengaruh yang positif dan signifikan antara penggunaan kartu debit dan $e$ money terhadap konsumsi.

Basri \& Sita (2018) selanjutunya meneliti mengenai pengaruh Alat Pembayaran Munggunakan Kartu (APMK) terhadap pola konsumsi masyarakat di Kota Palembang. Penelitian tersebut dilakukan dengan menyebar kuesioner kepada 200 responden sebagai sampel. Hasil penelitian menunjukkan bahwa APMK berpengaruh signifikan terhadap pola konsumsi. Penelitian selanjutnya mengenai pengaruh sistem transaksi non tunai terhadap tingkat konsumsi masyarakat di Surabaya. Penelitian tersebut menggunakan data dari Bank Indonesia dari tahun 2014-2017. Hasilnya menunjukkan adanya pengaruh satu arah pada tingkat konsumsi dengan menggunakan sistem transaksi APMK (Nelasari \& Cahyono, 2018).

Khairi \& Gunawan (2019) melakukan penelitian mengenai pengaruh penggunaan APMK dan e-money terhadap konsumsi masyarakat Aceh. Penelitian tersebut dilakukan terhadap 100 orang responden. Variabel dependen dalam penelitian adalah pengeluaran konsumsi masyarakat. Variabel independen adalah usia, jenis kelamin, jumlah anggota keluarga, pendapatan, penggunaan APMK dan $e$ money, serta religiusitas. Hasil penelitian tersebut mengungkapkan adanya pengaruh yang positif antar setiap variabel.

\section{METODE PENELITIAN}

Penelitian ini menggunakan pendekatan deskripftif kuntitatif yang bertujuan mendeskripsikan sesuatu untuk menggambarkan fakta dan populasi secara sistematis dan factual. Penelitian menggunakan data primer yang dikumpulkan dengan melakukan survei melalui penyebaran kuesioner. Objek penelitian ini adalah masyarakat Kota Batam. Penarikan sampel pada penelitian ini menggunakan purposive sampling yaitu berdasarkan kriteria sudah ditentukan. Adapun kriterianya sebagai berikut: sampel yang dipilih adalah pengguna aktif e-money berbasis aplikasi minimal enam bulan terakhir. Pernah melakukan 
transaksi menggunakan e-money berbasis aplikasi dalam sebulan terakhir. Sampel yang didapat pada penelitian ini sejumlah 318 responden.

\section{HASIL DAN PEMBAHASAN}

\section{Gambaran Umum Objek Penelitian}

Gambaran umum objek penelitian berdasarkan kelompok usia dapat dilihat pada gambar 1 berikut.

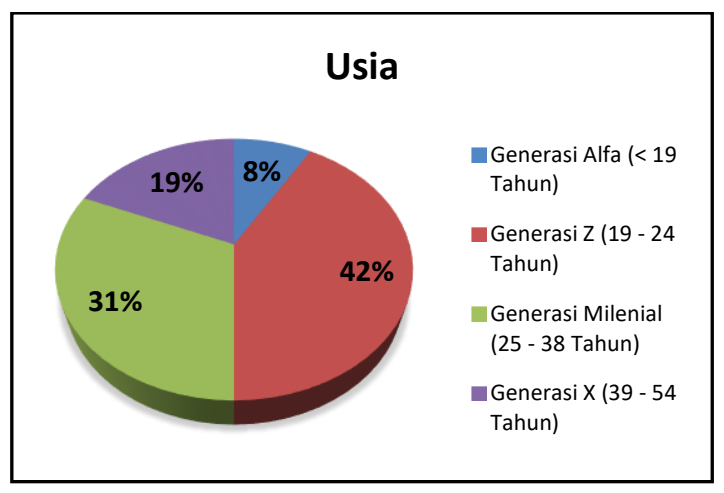

Gambar 1. Usia Responden

Berdasarkan gambar 1 diketahui bahwa mayoritas responden yang menjadi sampel penelitian adalah generasi $\mathrm{Z}$ dengan rentang usia 19-24 tahun. Selanjutnya disajikan gambaran objek penelitian berdasarkan jenis kelamin pada gambar 2 berikut.

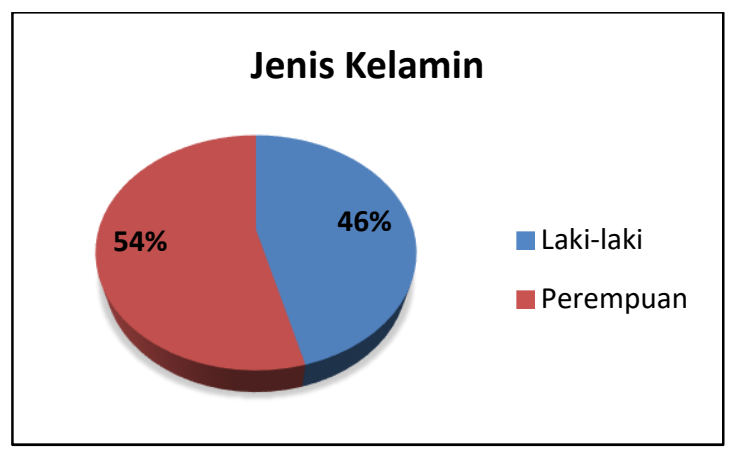

Gambar 2. Jenis Kelamin Responden

Berdasarkan gambar 2 diketahui bahwa responden berjenis kelamin perempuan lebih banyak (54\%) daripada responden berjenis kelamin laki-laki (46\%). Selanjutnya disajikan gambaran objek penelitian berdasarkan jenis pekerjaan. Hal ini dilakukan untuk mengetahui latar belakang pekerjaan responden.

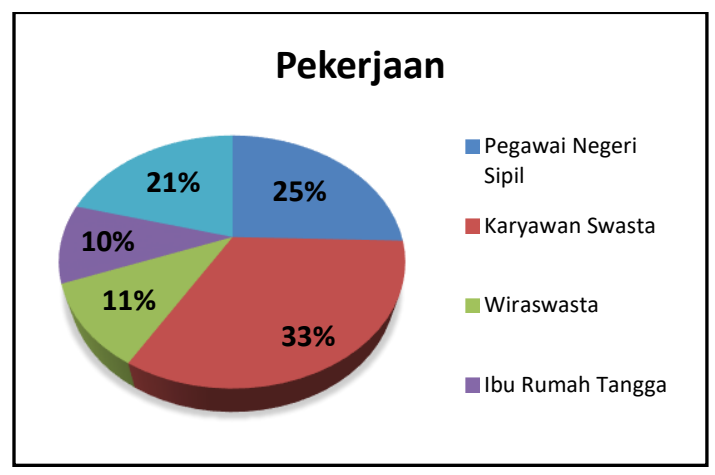

Gambar 3. Pekerjaan Responden

Berdasarkan gambar 3 diketahui responden terbanyak adalah karyawan swasta (33\%), kemudian PNS (25\%), pelajar/mahasiswa (21\%). Responden yang bekerja sebagai wiraswasta sebesar $11 \%$ dan terendah ibu rumah tangga $10 \%$.

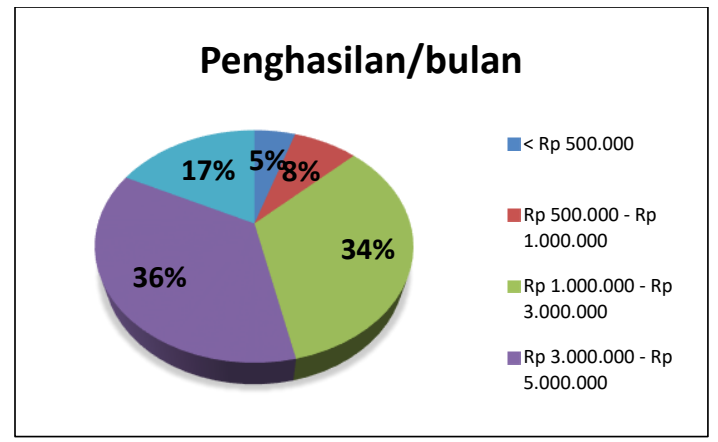

Gambar 4. Usia Responden

Berdasarkan gambar 4 responden terbanyak adalah penghasilan per bulan Rp 3.000.000 sampai Rp 5.000 .000 (36\%). Responden dengan penghasilan per bulan $<$ Rp 500.000 hanya sebesar $5 \%$.

\section{Penggunaan E-money Berbasis Aplikasi}

Berdasarkan data yang terkumpul, berikut disajikan ringkasan mengenai penggunaan e-money berbasis aplikasi dikalangan masyarakat Kota Batam.

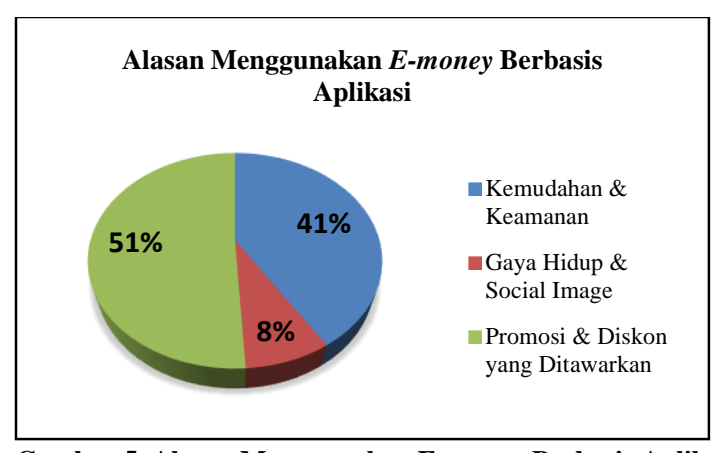

Gambar 5. Alasan Menggunakan E-money Berbasis Aplikasi 
Gambar 5 menunjukkan bahwa faktor promosi dan diskon yang ditawarkan memiliki persentase paling tinggi, yaitu sebesar $51 \%$. Selanjutnya diikuti oleh faktor kemudahan dan keamanan sebesar $41 \%$ serta gaya hidup dan social image yang hanya $8 \%$. Hal tersebut menunjukkan bahwa adanya promosi dan diskon menjadi daya tarik utama bagi masyarakat, meskipun keamanan belum sepenuhnya terjamin.

Frekuensi Penggunaan E-money Berbasis Aplikasi

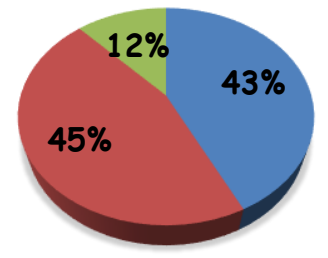

$$
\begin{aligned}
& <10 \text { Kali } \\
& 10-15 \text { Kali } \\
& >15 \text { Kali }
\end{aligned}
$$

Gambar 6. Frekuensi Penggunaan E-money Berbasis Aplikasi

Dapat dilihat pada gambar 6 bahwa masyarakat Kota Batam cukup sering menggunakan e-money berbasis aplikasi dengan rentang 10 sampai 15 kali dalam sebulan. Dengan demikian masyarakat Kota Batam belum sepenuhnya beralih kepada pembayaran dengan menggunakan e-money berbasis aplikasi. Hal tersebut juga disebabkan masih banyak pedagang dan penjual yang belum menerima sistem pembayaran non tunai tersebut, seperti di pasar tradisional di Kota Batam yang sampai saat ini masih menggunakan pembayaran secara tunai.

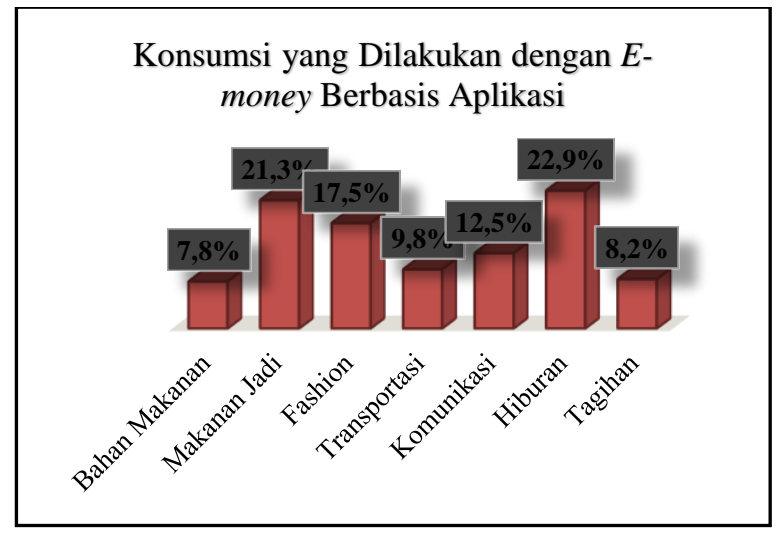

Gambar 7. Kelompok Transaksi Dengan Pembayaran Menggunakan E-money

Hasil penelilian menunjukkan setiap responden minimal menggunakan e-money untuk dua jenis kelompok konsumsi. Pada gambar 7 dapat terlihat bahwa kelompok konsumsi untuk hiburan seperti pembelian tiket bioskop, karaoke, hotel dan wisata paling tinggi. Diikuti dengan kelompok konsumsi makanan jadi dan fashion. Untuk transportasi dan komunikasi tidak terlalu tinggi. Kelompok konsumsi bahan makanan cenderung rendah, hal ini dikarenakan untuk pemenuhan bahan makanan masyarakat Kota Batam lebih banyak melakukan transaksi di pasarpasar tradisional dengan pembayaran tunai. Pembayaran tagihan juga belum banyak dilakukan dengan e-money, salah satu faktor adalah besarnya jumlah tagihan yang harus dibayarkan sehingga masyarakat merasa lebih aman dengan pembayaran tunai.

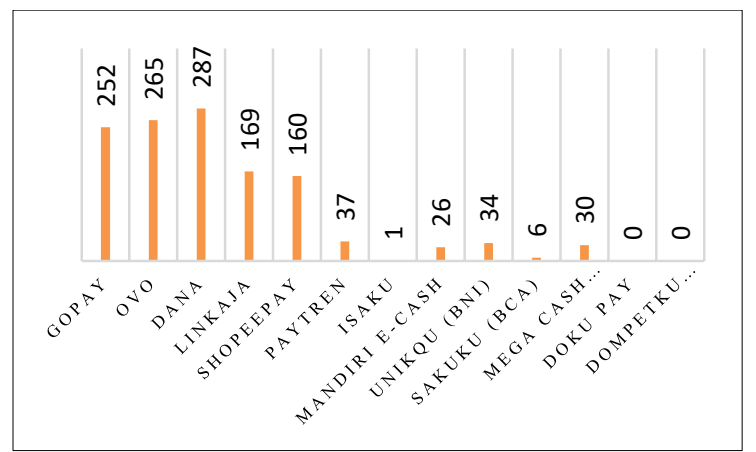

Gambar 8. E-money Berbasis Aplikasi yang Digunakan Masyarakat Kota Batam

Berdasarkan gambar 8 dapat terlihat masyarakat Kota Batam lebih banyak menggunakan e-money berbasis aplikasi yang disediakan pihak swasta. Terlihat dari diagram di atas tiga e-money dengan pengguna terbanyak adalah Dana, OVO dan Gopay. Hasil ini sesuai dengan hasil survei nasional yang dilakukan beberapa lembaga survei bahwa Dana, OVO dan Gopay masih memiliki pengguna yang terbanyak di Indonesia. Selain itu, Link aja yang merupakan $e$ money yang dikeluarkan oleh pemerintah Indonesia cukup diminati masyarakat. Hal ini dikarenakan Linkaja cukup banyak bekerjasama dengan beberapa BUMN, seperti Pertamina, PLN dan Telkomsel. Beberapa e-money yang dikeluarkan oleh lembaga keuangan atau perbankan juga belum banyak digunakan masyarakat.

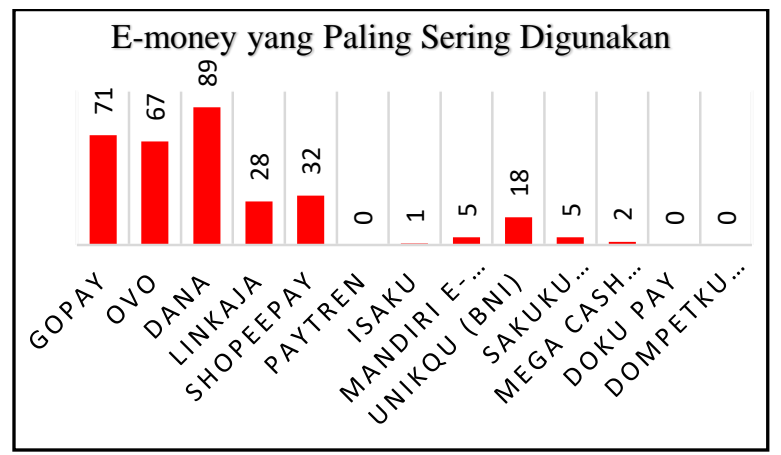


Gambar 9. Diagram E-money Berbasis Aplikasi yang Paling Sering Digunakan Masyarakat

Berdasarkan gambar 9 dapat terlihat bahwa pada masyarakat Kota Batam Dana Dompet Digital memiliki pengguna yang paling banyak dari 318 responden dalam penelitian ini, yaitu sebanyak 89 pengguna. Selanjutnya, diperingkat kedua ada Gopay dengan 71 pengguna dan peringkat ketiga ada OVO dengan 67 pengguna. Sementara untuk ShopeePay yang belakangan cukup gencar menawarkan promo dan diskon besar hanya sebanyak 32 pengguna. Linkaja milik pemerintah Indonesia yang bekerjasama dengan beberapa BUMN juga tidak terlalu banyak diminati masyarakat Kota Batam yang hanya 28 pengguna. Untuk E-money yang dikeluarkan oleh peyedia layanan keuangan atau perbankan masih kurang diminati oleh masyarakat Kota Batam.

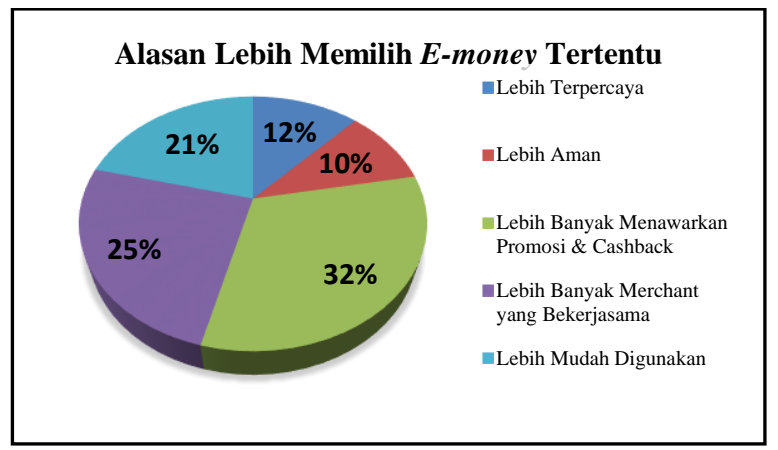

Gambar 10. Alasan Memilih E-money Berbasis Aplikasi

Gambar 10 menunjukkan bahwa penawaran promosi dan cashback masih cukup ampuh bagi masyarakat untuk menggunakan suatu produk atau jasa. $32 \%$ responden sering menggunakan $e$-money karena adanya diskon dan cashback. Sebanyak 25\% responden memilih suatu e-money dikarenakan banyaknya merchant yang bekerjasama, sehingga memungkinkan digunakan untuk transaksi yang beragam. Kemudahan dalam penggunaan juga miliki persentase yang cukup besar dalam memilih e-money yang digunakan yaitu sebesar $21 \%$. Untuk kepercayaan dan keamanan suatu e-money tidak terlalu berpengaruh dalam menentukan $e$-money yang akan digunakan. Pembahasan selanjutnya lebih mengarah kepada peningkatan konsumsi masyarakat dengan menggunakan $e$-money berbasis aplikasi,

Gambar 11 menunjukkan bahwa dari 318 responden sebanyak 267 responden (84\%) pengeluaran konsumsinya meningkat setelah menggunakan $e$ money. Sebanyak 51 responden (16\%) tidak mengalami peningkatan pengeluaran konsumsi setelah menggunakan e-money. Lebih jelas dapat dilihat pada gambar 12, dimana dari 267 responden, sebanyak 156 orang mengalami peningkatan antara Rp 500.000 sampai Rp 1.000.000. Selanjutnya 93 orang hanya mengalami peningkatan yang kurang dari Rp 500.000. Peningkatan paling tinggi terjadi pada 18 responden dimana peningkatan konsumsi lebih dari $\mathrm{Rp}$ 1.000 .000 .

\section{Peningkatan Konsumsi Setelah Menggunakan E-money Berbasis Aplikasi}

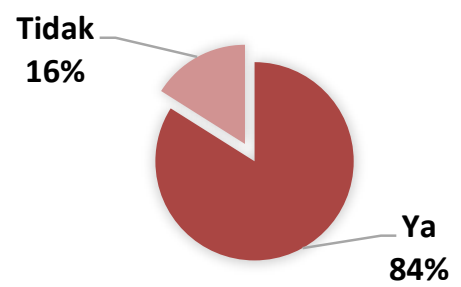

Gambar 11. Peningkatan Konsumsi dengan menggunakan $e$ money

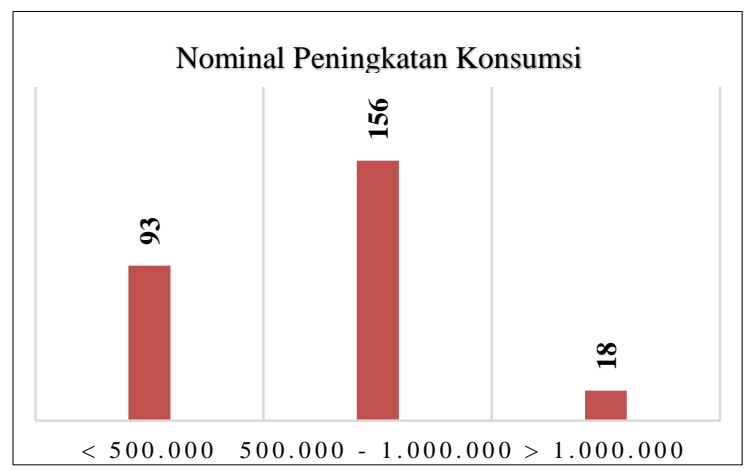

Gambar 12. Diagram Nominal Peningkatan Konsumsi

\section{Pengeluaran Konsumsi Makanan}

Berdasarkan data yang terkumpul, berikut disajikan jumlah rata-rata pengeluaran per bulan konsumsi makanan dengan menggunkan e-money berbasis aplikasi. Pengeluaran konsumsi makanan dikelompokkan menjadi enam kelompok, yaitu bahan makanan pokok (beras, gandum, dsb), bahan makanan nabati (sayuran dan buah), bahan makanan hewani (ayam, ikan dan daging), minumam, cemilan dan makanan jadi.

TABEl 1. RATA-RATA PENGELUARAN Konsumsi MAKANAN DENGan MENGgunaKan E-MONEy Berbasis APLIKASI PER BULAN

\begin{tabular}{lrc}
\hline \multicolumn{1}{c}{ Jenis } & rata-rata & $\%$ \\
\hline Konsumsi & 212.316 & 20,12 \\
Bahan Makanan Pokok & 179.120 & 16,98 \\
Bahan Makanan Nabati & 155.820 & 14,77 \\
Minuman & 121.116 & 11,48
\end{tabular}




\begin{tabular}{lccc} 
Cemilan & & 137.469 & 13,03 \\
Makanan Jadi & & 249.182 & 23,62 \\
& Total & & $\mathbf{1 0 0}$ \\
\hline
\end{tabular}

Berdasarkan tabel 1 di atas diketahui bahwa pengeluaran konsumsi makanan dengan menggunakan e-money berbasis aplikasi paling tinggi adalah kelompok konsumsi makanan jadi dengan persentase sebesar 23,62 \% atau rata-rata pengeluaran sebesar Rp 249.182 per bulan. Selanjutnya diikuti konsumsi bahan makanan pokok sebesar 20,12\% dengan ratarata pengeluaran sebulan sebanyak $\mathrm{Rp}$ 212.316. Kelompok konsumsi bahan makanan nabati dan hewani masing-masing memiliki nilai pengeluaran rata-rata per bulan sebesar 16,98\% atau Rp 179.120 dan 14,77 \% atau sebesar Rp 155.820. kelompok konsumsi untuk cemilan memiliki persentase pengeluaran per bulan sebesar $13,03 \%$ atau dalam rupiah sebesar $\mathrm{Rp}$ 137.469. Kelompok konsumsi minuman memiliki rata-rata pengeluaran terendah dengan persentase hanya sebesar $11,48 \%$ atau sebesar Rp 121.116 dalam sebulan.

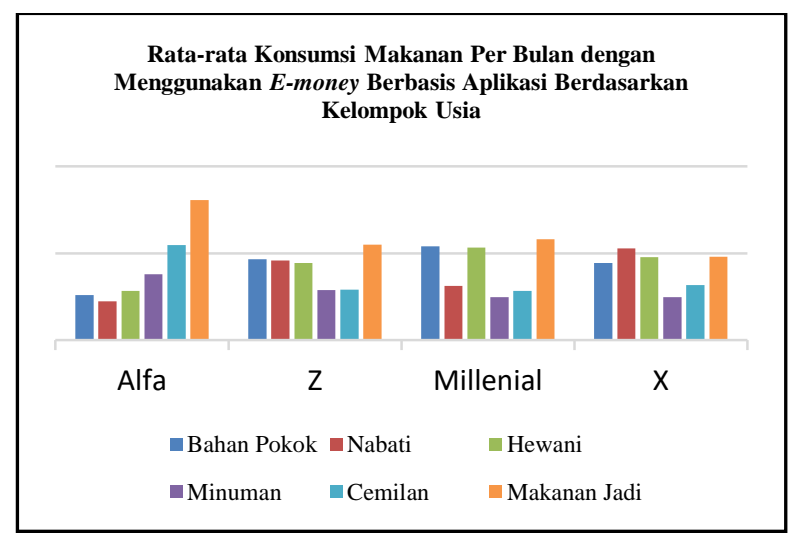

Gambar 12. Rata-rata Konsumsi Makanan Per Bulan dengan E-money Berbasis Aplikasi Berdasarkan Kelompok Usia

Secara umum rata-rata pengeluaran konsumsi makanan berdasarkan kelompok usia yang paling tinggi adalah kelompok makanan jadi. Hal ini terjadi pada setiap generasi, dimana yang paling tinggi tingkat konsumsinya adalah Generasi Alfa yaitu sebesar 32\% atau Rp 266.667 per bulan dari total konsumsi. Selanjutnya diikuti Generasi Milenial sebesar 23\% atau Rp 260.850, Generasi Z sebesar $22 \%$ atau Rp 249.583 dan Generasi X sebesar 19\% atau $\operatorname{Rp} 220.508$.

Sementara itu, untuk rata-rata pengeluaran konsumsi makanan dengan menggunakan e-money berbasis aplikasi berdasarkan kelompok usia yang paling rendah adalah konsumsi minuman. Rata-rata pengeluaran konsumsi minuman dengan menggunakan e-money berbasis aplikasi pada Generasi Z hanya $12 \%$ dari total konsumsi per bulan atau $\mathrm{Rp} 130.644$. Generasi Milenial hanya sebesar 10\% atau Rp 111.700 dan Generasi X juga hanya sebesar 10\% dari total ratarata konsumsi per bulan atau Rp 113.898. Perbedaan terjadi pada Generasi Alfa dimana pengeluaran konsumsi paling rendah adalah konsumsi bahan nabati yaitu hanya sebesar 9\% atau $\mathrm{Rp} 73.889$ dari total konsumsi per bulan.

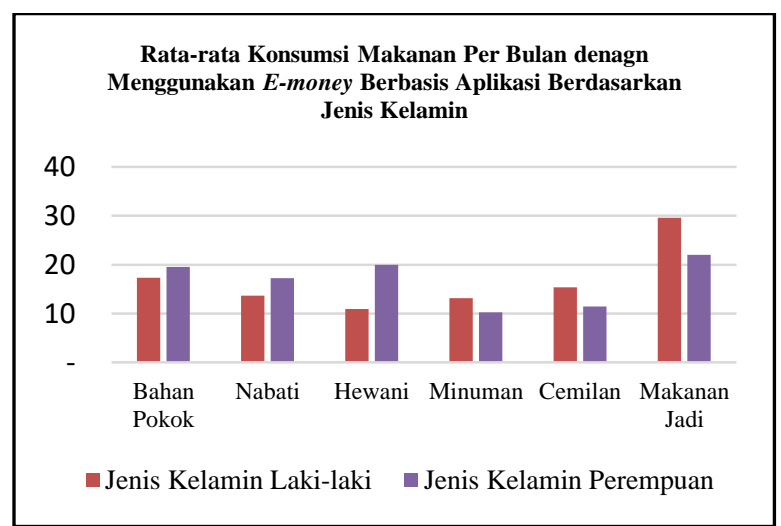

Gambar 13 Rata-rata Konsumsi Makanan dengan E-money Berbasis Aplikasi Per Bulan Berdasarkan Jenis Kelamin

Gambar 13 menunjukkan bahwa kelompok konsumsi makanan jadi merupakan konsumsi yang paling tinggi dikedua gender. Terjadi perbedaan dikedua gender untuk rata-rata konsumsi terendah, dimana perempuan konsumsi minuman yang terendah, sedangkan laki-laki konsumsi bahan hewani adalah yang terendah.

Secara rinci dapat dijelaskan bahwa untuk laki-laki pengeluaran konsumsi makanan jadi sebesar $30 \%$ dari total pengeluaran atau $\mathrm{Rp} 253.253$ per bulan. Selanjutnya diikuti bahan pokok yaitu $17 \%$ atau $\mathrm{Rp}$ 148.596, cemilan $15 \%$ atau Rp 131.402, bahan nabati $14 \%$ atau Rp 117.135, minuman sebesar $13 \%$ atau $\mathrm{Rp}$ 112.603 dan bahan hewani sebesar $11 \%$ atau hanya $\mathrm{Rp}$ 93.600 per bulan dari total rata-rata pengeluaran.

Rata-rata pengeluaran konsumsi makanan dengan menggunakan $e$-money berbasis aplikasi yang dilakukan oleh perempuan paling tinggi dialokasikan pada makanan jadi, sebesar 22\% atau Rp 273.387 per bulan. Konsumsi tertinggi selanjutnya adalah konsumsi bahan hewani sebesar Rp 245.727 dan konsumsi bahan pokok sebesar Rp 244.241. Konsumsi bahan nabati sebesar $17 \%$ atau Rp 215.675, cemilan sebesar $11 \%$ atau 142.616 dan terendah konsumsi minuman hanya sebesar $10 \%$ dari total pengeluaran per bulan atau Rp 128.343. 


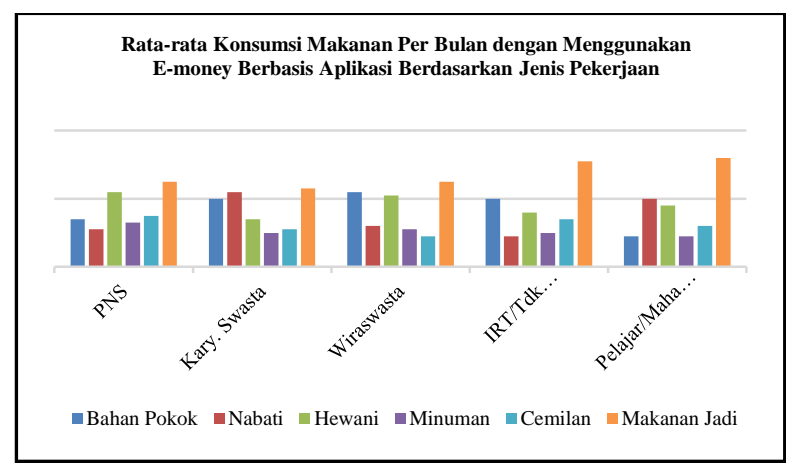

Gambar 14. Rata-rata Konsumsi Makanan dengan E-money Berbasis Aplikasi Per Bulan Berdasarkan Jenis Pekerjaan

Gambar 14 menunjukkan bahwa pengeluaran konsumsi makanan dengan menggunakan $e$-money berbasis aplikasi berdasarkan jenis pekerjaan yang paling tinggi adalah makanan jadi. Hal ini terjadi pada setiap kategori jenis pekerjaan. Hasil di atas menunjukkan bahwa pelajar/mahasiswa memiliki ratarata pengeluaran makanan jadi tertinggi sebesar 32\% atau Rp 396.154. Selanjutnya diikuti oleh ibu rumah tangga yang tidak bekerja sebesar $30 \%$ atau $\mathrm{Rp}$ 300.000 dan wiraswasta sebesar $25 \%$ atau rp 305.833 per bulan. PNS mengalokasikan pengeluaran dengan e-money berbasis aplikasi untuk makanan jadi sebesar 25\% atau $\mathrm{Rp} 275.062$ per bulan dari total pengeluarannya.Terakhir, karyawan swasta mengalokasikan sebesar $23 \%$ dari pengeluaran per bulan dengan menggunakan $e$-money berbasis aplikasi untuk makanan jadi.

Masing-masing jenis pekerjaan memiliki pengeluaran terendah yang beragam untuk konsumsi makanan. Responden yang bekerja sebagai PNS hanya mengalokasikan pengeluaran sebesar $11 \%$ atau $\mathrm{Rp}$ 121.139 per bulan dari total pengeluaran untuk bahan nabati. Karyawan swasta paling sedikit pengeluaran konsumsi makanan dengan e-money berbasis aplikasi adalah konsumsi minuman sebesar $10 \%$ atau $\mathrm{Rp}$ 112.286. Wiraswasta paling rendah pengeluaran konsumsi makanan adalah pada kelompok konsumsi cemilan yaitu sebesar 9\% atau 104.853 per bulannya. Sementara itu, ibu rumah tangga hanya mengalokasikan pengeluaran untuk bahan nabati sebesar $8,5 \%$ perbulan dari total pengeluarannya atau Rp 88.594. Responden yang masih berstatus pelajar atau mahasiswa, pengeluaran konsumsi terendah adalah untuk konsumsi bahan pokok yaitu hanya sebesar $8 \%$ atau 104.091 dari total pengeluaran per bulan.

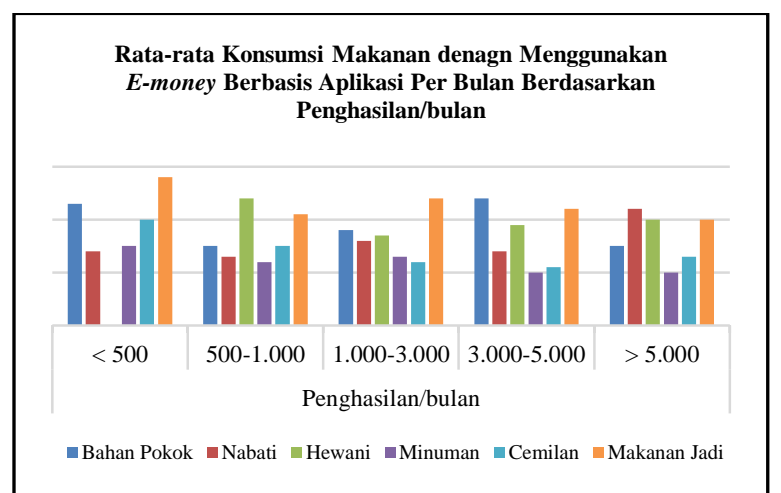

Gambar 15 Rata-rata Konsumsi Makanan dengan E-money Berbasis Aplikasi Per Bulan Berdasarkan Penghasilan/bulan

Responden dengan penghasilan $<\mathrm{Rp} 500.000$ paling banyak mengalokasi pengelurannya untuk membeli makanan jadi yaitu sebesar 28\% atau Rp 256.250 dari total pengeluaran. Responden pada kategori tersebut tidak ada mengalokasikan pengeluaran untuk konsumsi bahan pangan hewani, tetapi yang paling rendah adalah konsumsi bahan pangan nabati yaitu sebesar 14\% atau hanya Rp 132.143 per bulannya. Responden yang masuk dalam kategori penghasilan antara Rp 500.000 sampai Rp 1.000 .000 paling tinggi melakukan pengeluaran dengan e-money berbasis aplikasi untuk bahan pangan hewani sebesar $24 \%$ atau $\mathrm{Rp}$ 298.684. Sementara itu, pengeluaran terendah adalah untuk konsumsi minuman yang hanya sebesar $12 \%$ dari total pengeluran atau Rp 145.600. Kategori penghasilan antara $\mathrm{Rp} 1.000 .000$ sampai 3.000 .000 rata-rata tertinggi pengeluaran dengan e-money adalah untuk makanan jadi sebesar 25\% atau Rp 251.355. Rata-rata pengeluaran paling rendah adalah untuk konsumsi cemilan yang hanya 12,5\% perbulan atau Rp 124.813. Responden dengan penghasilan antara Rp 3.000.000 sampai Rp 5.000.000 pengeluaran konsumsi tertinggi adalah untuk bahan pokok sebesar $24 \%$ atau $\mathrm{Rp}$ 280.051. Konsumsi terendah untuk kategori penghasilan tersebut adalah untuk minuman yang hanya $10 \%$ dari rata-rata pengeluaran atau $\mathrm{Rp}$ 112.544. Responden dengan penghasilan > Rp 5.000.000 per bulan rata-rata pengeluaran makanan dengan e-money berbasis aplikasi adalah untuk kebutuhan bahan pangan nabati sebesar $21 \%$ atau $\mathrm{Rp}$ 235.784. Sementara itu, pengeluaran paling rendah kategori tersebut adalah untuk konsumsi cemilan sebesar10\% atau hanya 112.857 dari total rata-rata pengeluaran.

\section{Pengeluaran Konsumsi Non Makanan}

Pengeluaran konsumsi non makanan dikelompokkan menjadi enam kelompok, yaitu fasilitas rumah tangga (tagihan air, listrik dan TV kabel), transportasi, 
fashion, komunikasi, hiburan dan tagihan (pajak, asuransi dan BPJS).

TABEL 2. RATA-RATA PENGELUARAN KONSUMSI NON MAKANAN DENGAN MENGGUNAKAN E-MONEY BERBASIS APLIKASI PER BULAN

\begin{tabular}{lcc}
\hline \multicolumn{1}{c}{$\begin{array}{c}\text { Jenis } \\
\text { Konsumsi }\end{array}$} & rata-rata & \% \\
\hline Fasilitas Rumah Tangga & 524.667 & 32,23 \\
Transportasi & 207.028 & 12,72 \\
Fashion & 321.447 & 19,75 \\
Komunikasi & 131.321 & 8,07 \\
Hiburan & 278.491 & 17,11 \\
Tagihan & 164.890 & 10,13 \\
& & $\mathbf{1 0 0}$ \\
\hline
\end{tabular}

Berdasarkan tabel 2 diketahui bahwa pengeluaran konsumsi non makanan dengan menggunakan $e$ money berbasis aplikasi paling tinggi adalah kelompok konsumsi fasilitas rumah tangga dengan persentase sebesar 32,23\% atau rata-rata pengeluaran sebesar Rp 524.667 per bulan. Selanjutnya diikuti konsumsi untuk fashion sebesar $19.75 \%$ dengan rata-rata pengeluaran sebulan sebanyak Rp 321.447. Kelompok konsumsi untuk hiburan berada pada peringkat ketiga dengan persentase pengeluaran sebesar $17,11 \%$ atau rata-rata per bulan sebesar Rp 278.491. Kelompok konsumsi untuk transportasi selanjutnya memiliki persentase pengeluaran per bulan sebesar 12,72 \% atau dalam rupiah sebesar Rp 207.028. Konsumsi untuk tagihan sebesar $10,13 \%$ atau rata-rata $\mathrm{Rp} 164.843$ per bulan. Kelompok konsumsi untuk komunikasi memiliki ratarata pengeluaran terendah dengan persentase hanya sebesar 8,07 \% atau sebesar Rp 131.321 dalam sebulan.

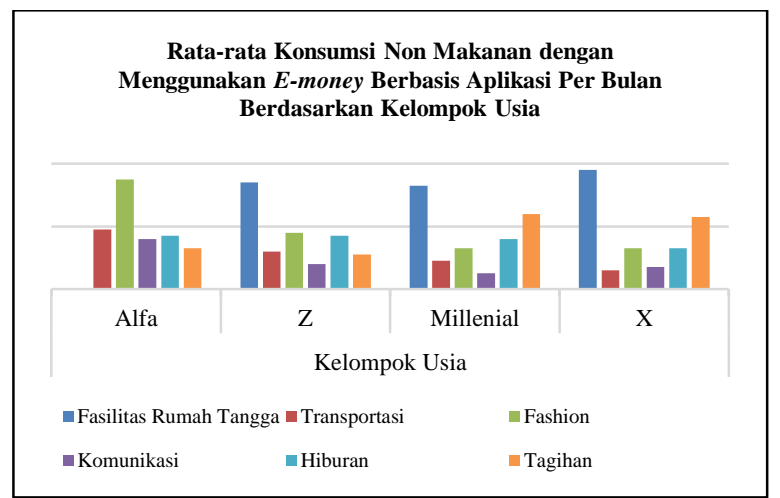

Gambar 16. Rata-rata Konsumsi Non Makanan Per Bulan dengan E-money Berbasis Aplikasi Berdasarkan Kelompok Usia

Gambar 16 menunjukkan rata-rata pengeluaran konsumsi non makanan per bulan dengan menggunakan $e$-money berbasis aplikasi berdasarkan karakteristik responden yaitu kelompok usia. Secara umum rata-rata pengeluaran konsumsi non makanan berdasarkan kelompok usia yang paling tinggi adalah pengeluaran untuk fasilitas rumah tangga. Generasi X tertinggi pengeluaran konsumsinya sebesar $38 \%$ atau $\mathrm{Rp}$ 886.429. Selanjutnya diikuti Generasi Z sebesar $33 \%$ atau Rp 747.571, Generasi Milenial sebesar 34\% atau Rp 640.956 perbulan dari total rata-rata pengeluaran. Generasi Alfa tidak sama sekali melakukan pengeluaran dengan e-money berbasis aplikasi untuk pembayaran fasilitas rumah tangga.

Sementara itu, terdapat perbedaan antara masingmasing generasi untuk pengeluaran konsumsi non makanan dengan menggunakan e-money berbasis aplikasi. Generasi Alfa pengeluaran konsumsi terendah adalah pembayarn tagihan yang hanya $13 \%$ atau Rp 159.375 dari total rata-rata pengeluaran. Generasi $\mathrm{Z}$ pengeluaran konsumsi terendah adalah untuk komunikasi yang hanya 8\% atau Rp 152.031 dari total rata-rata pengeluaran. Generasi Milenial hanya mengalokasikan sebesar 5\% atau Rp 119.381 perbulan untuk komunikasi. Sedangkan, Generasi X pengeluaran konsumsi terendah adalah untuk transportasi yang hanya 6,5\% atau Rp 154.068 per bulan.

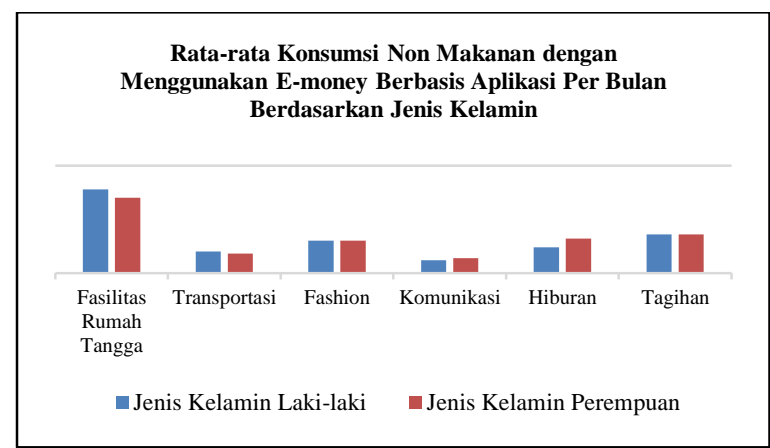

Gambar 17. Rata-rata Konsumsi Non Makanan Per Bulan dengan E-money Berbasis Aplikasi Berdasarkan Jenis Kelamin

Gambar 17 menunjukkan bahwa pengeluaran untuk fasilitas rumah tangga merupakan konsumsi dengan rata-rata yang paling tinggi dikedua gender. Rata-rata pengeluaran konsumsi terendah antara kedua gender juga sama yaitu pada pengeluaran untuk komunikasi.

Secara rinci dapat dijelaskan bahwa untuk lakilaki pengeluaran konsumsi fasilitas rumah tangga sebesar 39\% dari total pengeluaran atau Rp 942.805 per bulan. Terdapat perbedaan yang cukup signifikan dengan konsumsi lainnya seperti pembayaran tagihan sebesar $18 \%$ atau Rp 443.481, fashion $15 \%$ atau $\mathrm{Rp}$ 354.452 dan hiburan sebesar $12 \%$ atau Rp 297.956. Sedangkan untuk transportasi sebesar $10 \%$ atau Rp 236.233 dan komunikasi hanya sebesar $6 \%$ atau hanya Rp 154.296 per bulan dari total rata-rata pengeluaran. 
Rata-rata pengeluaran konsumsi non makanan dengan menggunakan e-money berbasis aplikasi yang dilakukan oleh perempuan paling tinggi dialokasikan pada pembayaran fasilitas rumah tangga, sebesar 35\% atau $\mathrm{Rp} 685.307$ per bulan. Konsumsi tertinggi selanjutnya adalah pembayaran tagihan sebesar $18 \%$ atau Rp 245.727 dan hiburan sebesar 17\% atau Rp 329.241. Rata-rata yang dialokasi untuk fashion sebesar 15\% atau Rp 293.430, transportasi sebesar 9\% atau 182.238 dan terendah pengeluaran untuk komunikasi yang hanya sebesar $7 \%$ dari total pengeluaran per bulan atau Rp 135.959.

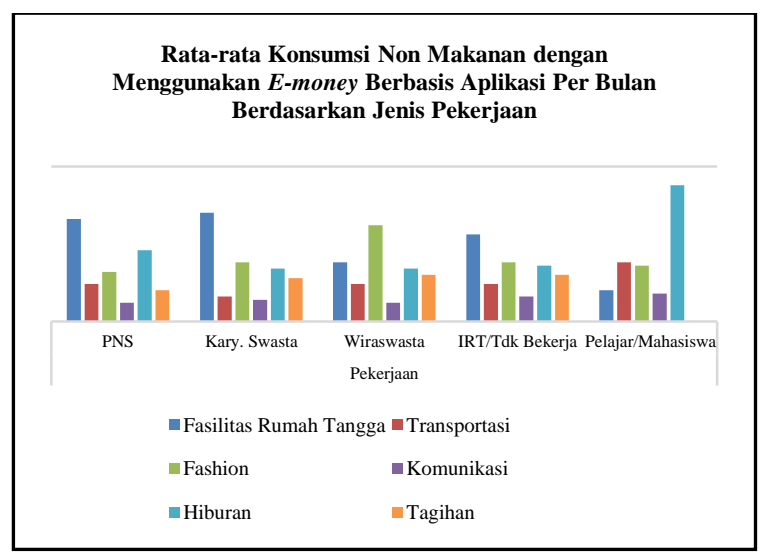

Gambar 18. Rata-rata Konsumsi Non Makanan Per Bulan dengan E-money Berbasis Aplikasi Berdasarkan Jenis Pekerjaan

Gambar 18 menunjukkan bahwa terdapat perbedaan pada masing-masing jenis pekerjaan untuk pengeluaran konsumsi non makanan dengan menggunakan $e$-money berbasis aplikasi. Histogram di atas menunjukkan bahwa responden yang nekerja sebagai PNS, karyawan swasta dan ibu rumah tangga pengeluaran tertinggi adalah untuk fasilitas rumah tangga. Besarnya pengeluaran masing-masing adalah sebesar 33\% atau Rp 838.044 untuk PNS, 35\% atau 684.211 untuk karyawan swasta dan 28\% atau Rp 454.997 untuk ibu rumah tangga. Perbedaan pada responden yang bekerja sebagai wiraswasta dimana pengeluaran tertinggi adalah untuk fashion sebesar $31 \%$ atau $\mathrm{Rp}$ 659.524. Pelajar/mahasiswa paling tinggi pengeluaran konsumsi dengan e-money berbasis aplikasi adalah untuk hiburan sebesar $44 \%$ dari total rata-rata pengeluaran per bulan.

Berdasarkan tabel dan histogram di atas juga dapat telihat bahwa pegeluaran terendah untuk seluruh kategori pekerjaan adalah untuk komunikasi. PNS hanya mengalokasikan sebesar 6\% atau Rp 148.101 dari rata-rata konsumsi dengan e-money berbasis aplikasi. Karyawan swasta mengalokasikan sebesar 7\% atau Rp 142.043 perbulannya untuk komunikasi. Wiraswasta mengalokasikan sebesar $6 \%$ atau hanya
Rp 131.290 dari rata-rata pengeluaran per bulan menggunakan e-money berbasis aplikasi. Ibu rumah tangga sebesar 8\% atau Rp 125.357 untuk komunikasi. Pelajar/mahasiswa hanya mengalokasikan 9\% atau hanya Rp 153.636 untuk komunikasi dari total ratarata pengeluaran konsumsi non makanan. Kategori pelajar/mahasiswa juga tidak ada melakukan pengeluaran dengan $e$-money berbasis aplikasi untuk fasilitas rumah tangga. Berdasarkan uraian tersebut, maka dapat terlihat bahwa untuk komunikasi seluruh kategori pekerjaan hanya mengalokasikan kurang dari $10 \%$ dari total rata-rata pengeluaran konsumsi non makanan dengan $e$-money berbasis aplikasi.

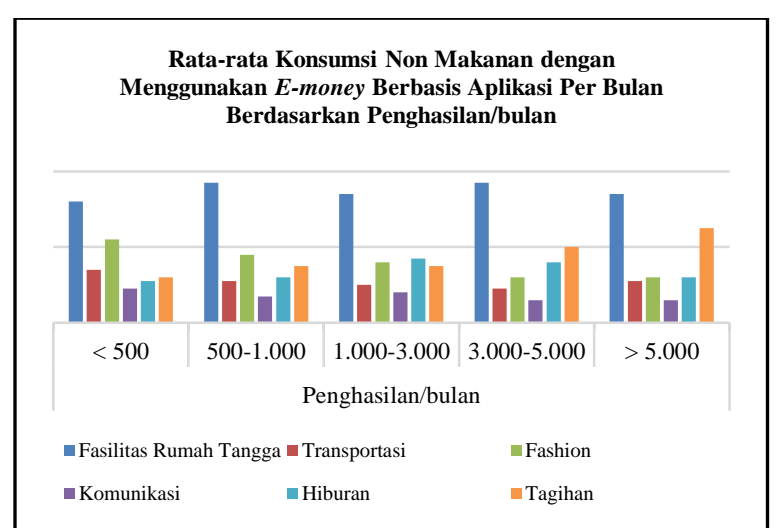

Gambar 19. Rata-rata Konsumsi Non Makanan Per Bulan dengan E-money Berbasis Aplikasi Berdasarkan Penghasilan/bulan

Berdasarkan gambar 19 dapat dilihat bahwa pengeluaran konsumsi non makanan dengan menggunakan $e$-money berbasis aplikasi berdasarkan penghasilan/bulan adalah sama tiap-tiap kategotri. Rata-rata pengeluaran konsumsi tertinggi setiap kategori penghasilan adalah untuk pengeluaran fasilitas rumah tangga. Responden dengan penghasilan < Rp 500.000 mengalokasi pengelurannya untuk fasilitas rumah tangga sebesar 32\% atau Rp 284.500 dari total pengeluaran. Kategori penghasilan antara $\mathrm{Rp}$ 500.000 sampai Rp 1.000.000 pengeluaran dengan $e$ money berbasis aplikasi untuk fasilitas rumah tangga sebesar 37\% atau $\mathrm{Rp}$ 602.381. Kategori penghasilan antara Rp 1.000.000 sampai 3.000 .000 rata-rata tertinggi pengeluaran dengan e-money adalah untuk fasilitas rumah tangga sebesar $34 \%$ atau $\mathrm{Rp} 720.455$. Responden dengan penghasilan antara $\mathrm{Rp} 3.000 .000$ sampai $\mathrm{Rp}$ 5.000.000 pengeluaran untuk fasilitas rumah tangga sebesar 37\% atau $\mathrm{Rp}$ 737.345. Responden dengan penghasilan > Rp 5.000.000 per bulan rata-rata pengeluaran non makanan dengan $e$ money berbasis aplikasi adalah untuk fasilitas rumah tangga sebesar 34\% atau Rp 888.043.

Pengeluaran konsumsi terendah setiap kategori penghasilan adalah untuk komunikasi. Responden 
dengan penghasilan < Rp 500.000 mengalokasi pengelurannya untuk komunikasi sebesar $9 \%$ atau Rp 81.818 dari total pengeluaran. Kategori penghasilan antara Rp 500.000 sampai Rp 1.000.000 pengeluaran dengan e-money berbasis aplikasi untuk komunikai sebesar 7\% atau $\mathrm{Rp} 120.000$. Kategori penghasilan antara Rp 1.000 .000 sampai 3.000 .000 rata-rata tertinggi pengeluaran dengan e-money adalah untuk komunikasi sebesar 8\% atau Rp 176.458. Responden dengan penghasilan antara $\mathrm{Rp} 3.000 .000$ sampai $\mathrm{Rp}$ 5.000 .000 pengeluaran untuk komunikasi sebesar $6 \%$ atau Rp 117.358. Responden dengan penghasilan > Rp 5.000.000 per bulan rata-rata pengeluaran non makanan dengan e-money berbasis aplikasi adalah untuk komunikasi sebesar 6\% atau Rp 167.692.

\section{Pola Konsumsi Masyarakat}

Berdasarkan analisis hasil yang telah dilakukan berdasarkan kelompok usia, generasi milenial merupakan generasi dengan rata-rata pengeluaran konsumsi dengan e-money berbasis aplikasi tertinggi. Hal ini sejalan dengan (Lyons, 2004) yang menyebutkan ciri-ciri generasi milenial: karakteristik masing-masing individu berbeda, tergantung dimana ia dibesarkan, strata ekonomi, dan sosial keluarganya, pola komunikasinya sangat terbuka dibanding generasi-generasi sebelumnya, pemakai media sosial yang fanatik dan kehidupannya sangat terpengaruh dengan perkembangan teknologi, lebih terbuka dengan pandangan politik dan ekonomi, sehingga mereka terlihat sangat reaktif terhadap perubahan lingkungan yang terjadi di sekelilingnya, memiliki perhatian yang lebih terhadap kekayaan.

Berdasarkan jenis kelamin, pengeluaran konsumsi mayarakat dengan menggunakan e-money antara laki-laki dan perempuan tidak jauh berbeda. Konsumsi makanan pada perempuan lebih banyak untuk bahan makanan yang masih harus diolah seperti bahan pokok, bahan makanan nabati dan bahan makanan hewani. Berbeda dengan laki-laki yang konsumsi makanan paling tinggi untuk makanan yang instan seperti cemilan, minuman dan makanan jadi. Hal ini sejalan pada kenyataannya bahwa laki-laki cenderung untuk memilih sesuatu yang cepat dan instan. Konsumsi non makanan antara laki-laki dan perempuan juga relatif sama, terutama untuk fashion dan pembayaran tagihan. Untuk komunikasi dan hiburan rata-rata konsumsi lebih tinggi dilakukan oleh perempuan. Sedangkan laki-laki lebih tinggi untuk konsumsi transportasi dan pengeluaran untuk fasilitas rumah tangga.
Berdasarkan jenis pekerjaan, rata-rata pengeluaran tertinggi dengan menggunakan e-money berbasis aplikasi seluruh kategori pekerjaan adalah untuk makanan jadi yang merupakan kebutuhan utama masyarakat. Perbedaan terjadi pada pengeluaran konsumsi non makanan dimana fasilitas rumah tangga rata-rata pengeluaran cukup tinggi untuk PNS, karyawan swasta dan ibu rumah tangga. Bagi para wiraswasta yang didominasi oleh perempuan pengeluaran untuk fashion paling tinggi. Pelajar/mahasiswa paling banyak pengeluarannya untuk hiburan.

Berdasarkan penghasilan/bulan secara umum dapat dilihat bahwa pengeluaran yang dilakukan tidak lebih besar dari pendapatan yang diterima. Hal ini sejalan dengan Teori Keynes bahwa konsumsi sangat dipengaruhi oleh besarnya pendapatan.

Selanjutnya disajikan ringkasan rata-rat pengeluaran konsumsi masyarakat dengan menggunakan e-money berbasis aplikasi, distribusi frekuensi dan tingkat kecenderungan dari masingmasing kelompok konsumsi makanan dan non makanan.

TABEL 3. RINGKASAN PENGELUARAN KONSUMSI DENGAN MENGGUNAKAN E-MONEY BERBASIS APLIKASI

\begin{tabular}{|c|c|c|c|c|c|c|}
\hline \multirow{2}{*}{$\begin{array}{l}\text { No } \\
1\end{array}$} & \multirow{2}{*}{$\begin{array}{l}\text { Jenis Konsumsi } \\
\text { Bahan Pokok }\end{array}$} & \multirow{2}{*}{$\begin{array}{l}\begin{array}{l}\text { Rata- } \\
\text { rata }\end{array} \\
212.316\end{array}$} & \multicolumn{3}{|c|}{ Modus Interval } & \multirow{2}{*}{$\begin{array}{l}\text { Kategor } \\
\text { Rendah }\end{array}$} \\
\hline & & & 35.000 & - & 355.267 & \\
\hline 2 & $\begin{array}{l}\text { Bahan Makanan } \\
\text { Hewani }\end{array}$ & 155.820 & 20.000 & - & 233.872 & Rendah \\
\hline 3 & $\begin{array}{l}\text { Bahan Makanan } \\
\text { Nabati }\end{array}$ & 179.120 & 20.000 & - & 233.872 & Rendah \\
\hline 4 & Minuman & 121.116 & 71.850 & - & 123.698 & Rendah \\
\hline 5 & Cemilan & 137.469 & 30.000 & - & 102.372 & Rendah \\
\hline 6 & Makanan Jadi & 249.182 & 181.747 & - & 353.493 & Rendah \\
\hline 7 & $\begin{array}{l}\text { Fasilitas Rumah } \\
\text { Tangga }\end{array}$ & 524.667 & 681.898 & - & 892.529 & Rendah \\
\hline 8 & Transportasi & 207.028 & 20.000 & - & 125.856 & Rendah \\
\hline 9 & Fashion & 321.447 & 100.000 & - & 305.231 & Rendah \\
\hline 10 & Komunikasi & 131.321 & 98.609 & - & 147.217 & Rendah \\
\hline 11 & Hiburan & 278.491 & 276.839 & - & 352.451 & Rendah \\
\hline 12 & Tagihan & 164.890 & 50.000 & - & 368.647 & Rendah \\
\hline
\end{tabular}

Pengeluran konsumsi untuk makanan dalam penelitian ini dikelompokkan menjadi enam kelompok konsumsi. Pengeluaran dengan menggunakan e-money berbasis aplikasi untuk kelompok konsumsi pangan dasar seperti bahan pokok, bahan makanan nabati serta bahan makanan hewani masih sangat sedikit dan masuk dalam kategori rendah. Salah satu faktor paling mempengaruhi adalah budaya (culture) masyarakat Kota Batam yang masih melakukan transaksi secara tunai di pasar-pasar tradisional. Selain itu budaya 
tawar menawar di pasar tradisional yang dilakukan antara penjual dan pembeli hingga saat ini masih tetap terjaga. Fakta dilapangan juga diketahui sampai saat ini belum ada pasar tradisional di Kota Batam yang menggunakan sistem pembayaran secara elektronik.

Pengeluaran masyarakat Kota Batam untuk konsumsi minuman, cemilan dan makanan jadi juga masih dalam kategori rendah. Berdasarkan hasil penelitian konsumsi untuk kelompok tersebut cukup rutin namun masih dalam jumlah nominal yang tidak tinggi. Hal tersebut menunjukkan bahwa masyarakat Kota Batam belum sepenuhnya beralih pada pembayaran secara elektronik dalam pemenuhan konsumsi makanan.

Pengeluaran konsumsi untuk fasilitas rumah tangga, transportasi, fashion, komunikasi, hiburan dan tagihan merupakan konsumsi yang masuk dalam kategori non makanan. Berdasarkan hasil penelitian yang telah dihitung sebelumnya, diketahui untuk kelompok konsumsi fasilitas rumah tangga seperti pembayaran air, listrik dan TV kabel masih sangat rendah. Dari seluruh responden hanya 201 responden yang menggunakan e-money untuk pembayaran fasilitas rumah tangga. Faktor keamanan menjadi pertimbangan utama masyarakat untuk tidak melakukan pembayaran dengan e-money berbasis aplikasi. Hal ini juga disebabkan oleh jumlah nominal untuk pengeluaran fasilitas rumah tangga yang relatif besar, sehingga masyarakat lebih merasa aman membayar secara langsung. Resiko seperti saldo yang tiba-tiba hilang dan resiko lain juga menjadi pertimbangan masyarakat untuk menggunakan $e$ money berbasis aplikasi untuk kelompok konsumsi tersebut.

Kelompok konsumsi transportasi, fashion, komunikasi dan hiburan juga masih rendah jika pembayaran dilakukan dengan menggunakan e-money berbasis aplikasi. Rendahnya pengeluaran untuk komunikasi dengan e-money dikarenakan masyarakat lebih memilih membeli secara langsung, dengan harga yang sama tetapi lebih praktis tanpa harus melakukan transfer saldo terlebih dahulu, lalu kemudian digunakan untuk bertranskasi. Untuk kelompok hiburan, rendah nya pembayaran dengan e-money disebabkan masih belum banyak promosi yang ditawarkan untuk keperluan hiburan seperti tiket wisata dan hotel. Selain itu, kebutuhan akan hiburan juga tidak terlalu tinggi pada kelompok usia tertentu.

Pengeluaran dengan menggunakan e-money berbasis aplikasi untuk kelompok konsumsi tagihan seperti pembayaran pajak kendaraan, asuransi kesehatan dan BPJS masih rendah. Terdapat beberapa faktor yang menyebabkan masyarakat tidak menggunakan pembayaran secara elektronik untuk kelompok konsumsi tersebut. Pertama, untuk pembayaran pajak kendaraan tidak rutin setiap bulan dikeluarkan, biasanya hanya setahun sekali paling minimal. Kedua, beberapa instansi pemerintahan atau perusahaan langsung melakukan pemotongan untuk asuransi kesehatan dan BPJS dari gaji yang diperoleh pekerja.

Berdasarkan analisis yang telah dilakukan dapat diketahui bahwa secara keseluruhan pola konsumsi masyarakat Kota Batam dengan menggunakan $e$ money berbasis aplikasi tidak mengalami perubahan yang signifikan. Perhitungan yang telah dilakukan sebelumnya menunjukkan bahwa pergeseran hanya terjadi dengan meningkatnya pengeluaran untuk hiburan dibandingkan dengan kelompok konsumsi lainnya.

Pada tabel 3 dapat dilihat bahwa kecenderungan dari seluruh kelompok konsumsi baik makanan maupun non makanan berada pada kategori rendah. Tingkat konsumsi dengan menggunakan $e$-money yang masih rendah tersebut disebabkan oleh tiga faktor seperti, keamanan (security), kemudahan (ease to use) dan kegunaan (usability) (Utami, 2017). Berdasarkan analisis hasil yang telah dilakukan dapat diketahui bahwa secara keseluruhan pola konsumsi masyarakat Kota Batam dengan menggunakan e-money berbasis aplikasi tidak mengalami perubahan yang signifikan. Hasil penelitian ini tidak mendukung penelitian Dias, Silva \& Dias (2000) yang menunjukkan bahwa uang digital berpengaruh terhadap perekonomian dengan adanya pergeseran konsumsi masyarakat yang cukup besar dari makanan ke non makanan. Hasil penelitian ini juga tidak sejalan dengan penelitia Basri \& Sita (2018) yang menunjukkan bahwa APMK berpengaruh signifikan terhadap pola konsumsi masyarakat Kota Palembang. Perhitungan yang telah dilakukan sebelumnya menunjukkan bahwa pergeseran hanya terjadi dengan meningkatnya pengeluaran untuk hiburan, tetapi tidak signifikan. Hasil penelitian ini tidak sesuai teori konsumsi menurut Ernst Engel (1821-1896) yang menyatakan bahwa tingkat kesejahteraan dikatakan membaik bila perbandingan pengeluaran untuk konsumsi makanan cenderung semakin menurun dan sebaliknya pengeluaran untuk non makanan semakin meningkat.

\section{KESIMPULAN DAN SARAN}

Beberapa kesimpulan yang dapat diambil dari hasil penelitian ini sebagai berikut:

a. Dana menjadi $e$-money berbasis aplikasi yang paling sering digunakan oleh masyarakat 
Kota Batam dengan persentase $28 \%$ atau sebanyak 89 responden dari 318 sampel penelitian. Gopay meduduki peringkat kedua e-money yang paling sering digunakan masyarakat Kota Batam dengan persentase $22,3 \%$ atau sebanyak 71 responden. OVO berada pada peringkat ketiga dengan persentase $21,1 \%$ atau sebanyak 67 responden.

b. Berdasarkan karakteristike responden kelompok usia, Generasi milenial memiliki rata-rata pengeluaran konsumsi tertinggi. Berdasarkan jenis kelamin tidak terdapat perbedaan antara pengeluaran laki-laki dan perempuan. Berdasarkan jenis pekerjaan makanan jadi masih menjadi konsumsi tertinggi dan berdasarkan peghasilan/bulan rata-rata pengeluran masyarakat dengan $e$ money berbasis aplikasi tidak lebih dari pendapatan yang diterima.

c. Konsumsi bahan pokok seperti beras dan gandum dengan menggunakan $e$-money berbasis aplikasi masih dalam kategori rendah. Sebanyak 57 responden dari 318 sampel sama sekali tidak menggunakan $e$ money berbasis aplikasi dalam konsumsi bahan pokok.

d. Konsumsi bahan makanan hewani seperti ikan, ayam dan daging serta konsumsi bahan makanan nabati seperti sayuran dan buahbuahan dengan menggunakan e-money berbasis aplikasi masih sangat rendah.

e. Konsumsi minuman, cemilan dan makanan jadi dengan menggunakan e-money berbasis aplikasi masih dalam kategori rendah.

f. Konsumsi untuk fasilitas rumah tangga seperti pembayaran tagihan air, listrik dan TV kabel dengan menggunakan e-money berbasis aplikasi masih sangat rendah.

g. Konsumsi untuk transportasi seperti pembayaran untuk transportasi umum dan kendaraan pribadi dengan menggunakan $e$ money berbasis aplikasi masih rendah.

h. Konsumsi untuk fashion seperti pembelian baju, tas sepatu dan lainnya dengan menggunakan e-money berbasis aplikasi masih rendah.

i. Konsumsi untuk komunikasi seperti pembelian pulsa internet dan pulsa reguler dengan menggunakan e-money berbasis aplikasi masih rendah.

j. Konsumsi untuk hiburan seperti pembayaran tiket bioskop, wisata, karaoke dan lainnya dengan menggunakan e-money berbasis aplikasi masih rendah. k. Konsumsi untuk tagihan seperti pembayaran pajak, asuransi kesehatan dan BPJS dengan menggunakan e-money berbasis aplikasi masih sangat rendah.

1. Pola konsumsi masyarakat Kota Batam dengan menggunakan e-money berbasis aplikasi hanya sedikit mengalami pergeseran yaitu dengan meningkatnya pengeluaran untuk konsumsi kelompok hiburan. Sistem pembayaran dengan menggunakan $e$-money khususnya yang berbasis aplikasi juga belum menjadi pilihan pilihan utama masyarakat dalam bertransaksi.

Terdapat beberapa keterbatasan dalam penelitian ini sebagai berikut: pertama, Banyaknya jumlah responden dan metode pengumpulan data dengan menyebarkan kuesioner secara online diharapkan dapat memberikan jawaban yang sesuai dengan keadaan yang sesungguhnya, tetapi faktanya masih mengalami kesulitan untuk mendapatkan jawaban yang diharapkan karena peneliti tidak dapat mengontrol responden satu per satu dalam menjawab kuesioner. Kedua, Peneliti tidak melakukan wawancara atau deep interview, sehingga kesimpulan hanya berdasarkan data yang terkumpul melalui kuesioner. Ketiga, Peneliti belum merinci jenis konsumsi bahan pokok sehingga hasilnya hanya terbatas pada konsumsi bahan pokok secara umum dengan menggunakan $e$-money berbasis aplikasi

Berdasarkan keterbatasan masalah yang telah diuraikan di atas, terdapat beberapa saran untuk penelitian selanjutnya sebagai berikut: pertama, penelitian selanjutnya diharapkan dapat menambahkan metode wawancara untuk mendapatkan hasil yang lebih baik dan lebih mendalam. Kedua, penelitian selanjutnya diharapkan dapar menggunakan pengukuran yang berbeda dalam penelitiannya agar dapat melihat perbandingan dari hasil penelitain. Ketiga, penelitian selanjutnya diharapkan dapat mengembangkan populasi dan lokasi penelitian. Keempat, penelitian selanjutnya diharapkan memperluas usia sampel untuk mendapatkan hasil yang lebih spesifik. Kelima, penelitian selanjutnya diharapkan untuk melakukan pengujian validitas dan reliabilitas pada kuesioner terlebih dahulu. 


\section{DAFTAR PUSTAKA}

A. Ajzen, I. (1991). The Theory of Planned Behavior. Organizational Behavior and Human Decision Processes. 50 (2), 179-211.

B. Amirin, T., (2011). Populasi dan Sampel Penelitian 4: Ukuran Sampel Rumus Slovin, Erlangga, Jakarta.

C. Basri, H., \& Seto, A. A. (2018). Pengaruh Alat Pembayaran Menggunakan Kartu (APMK) Terhadap Pola Konsumsi Masyarakat di Kota PAlembang. Jurnal Adminika Politeknik Anika Palembang.

D. Cobla, G. M., \& Osei-Assibey, E. (2018). Mobile money adoption and spending behaviour: the case of students in Ghana. International Journal of Social Economics, Vol.45 No.1, 38.

E. Davis, F. D. (1985). A Technology Acceptance Model for Empirically Testing New End-User Information Systems: Theory and Result. Massachusetts Institute of Technology.

F. Dias, J., Silva, M. J., \& Dias, M. H. (2000). The Demand for Digital Money and its Impact on the Economy. Brazilian Electronic Journal of Economics.

G. Farida, N., Ardyan, A., \& Nuryakin. (2016). Gender Differences in Interest in Using Electronic Money: An Application of Theory Planned Behavior. International Review of Management and Marketing, 898-903.

H. Fatmasari, D., Waridin., Kurnia, A. S., \& Amin, R. (2019). Use of E-money and Debit Cards in Student Consumption Behavior . E3S Web of Conferences 125.

I. Igamo, A. M., \& Falianty, T. A. (2018). The Impact of Electronic Money on The Efficiency of The Payment System And The Substitution of Cash In Indonesia . Sriwijaya International Journal of Dynamic Economics and Business, 237-254.

J. Jogiyanto, H.M, (2011). Metode Penelitian Bisnis : Salah Kaprah dan Pengalamanpengalaman, Yogyakarta : BPFE

K. Khairi, M. R., \& Gunawan, E. (2019). Analisis Penggunaan Alat Pembayaran Menggunakan Kartu dan E-Money Terhadap Konsumsi Masyarakat di Banda Aceh. Jurnal Ilmiah Mahasiswa Ekonomi Islam.
L. Lyons, S. (2004). An Exploration of Generational Value in Life and at Work. Proquest Dissertation and Theses, 441.

M. Nelasari, P. R., \& Cahyono, H. (2018). Pengaruh Sistem Transaksi Non Tunai Terhadap Tingkat Konsumsi Masyarakat di Surabaya. Jurnal Ekonomi Islam, 165-171.

N. Nelasari, P. R., \& Cahyono, H. (2018). Pengaruh Sistem Transaksi Non Tunai Terhadap Tingkat Konsumsi Masyarakat di Surabaya. Jurnal Ekonomi Islam, 165-171.

O. Nicholson, walter. 1997. Intermediet Micro

P. economics and its aplication 7th Edi-

Q. tion. The dryden press.

R. Nicholson, walter. (1997). Intermediate Micro Economics and its Aplication 7th Edition. The dryden press.

S. Perkasa, A. A. (2014). Faktor-Faktor yang Mempengaruhi Pola Konsumsi Mahasiswa Universitas Hasanuddin. Skripsi: Universitas Hasanuddin.

T. Ramadhani, L. (2016). Pengaruh Penggunaan Kartu Drbit dan Uang Elektronik (E-money) Terhadap Pengeluaran Konsumsi Mahasiswa. JESP, 8(1)

U. Sugiyono. (2010). Metode Penelitian Pendidikan Pendekatan Kuantitatif, Kualitatif, dan R\&D. Bandung: Alfabeta

V. Suharni. (2018). Uang Elektronik (E-money) Ditinjau dari Perspektif Hukum dan Perubahan Sosial . Jurnal Spektrum Hukum.

W. Utami, S. S. (2017). Faktor-faktor yang Mempengaruhi Minat Menggunakan Emoney (Studi pada Mahasiswa STIE Ahmad Dahlan Jakarta). Jurnal Balance, 29-41.

X. Wulandari, D., Soseco, T., \& Narmaditya, B. S. (2016). Analysis of the Use of Electronic Money in Efforts to Support the Less Cash Society . International Finance and Banking 